Citation: M. Esterio, C. Osorio-Navarro, M. Azócar, C. Copier, M. Rubilar, L. Pizarro, J. Auger (2021) Reduced fitness cost and increased aggressiveness in fenhexamid-resistant Botrytis cinerea field isolates from Chile. Phytopathologia Mediterranea 60(1): 69-77. doi: 10.36253/phyto-10723

Accepted: November 3, 2020

Published: May 15, 2021

Copyright: (C2021 M. Esterio, C. OsorioNavarro, M. Azócar, C. Copier, M. Rubilar, L. Pizarro, J. Auger. This is an open access, peer-reviewed article published by Firenze University Press (http://www.fupress.com/pm) and distributed under the terms of the Creative Commons Attribution License, which permits unrestricted use, distribution, and reproduction in any medium, provided the original author and source are credited.

Data Availability Statement: All relevant data are within the paper and its Supporting Information files.

Competing Interests: The Author(s) declare(s) no conflict of interest.

Editor: Tito Caffi, Università Cattolica del Sacro Cuore, Piacenza, Italy.
Research Papers

\section{Reduced fitness cost and increased aggressiveness in fenhexamid-resistant Botrytis cinerea field isolates from Chile}

\author{
Marcela ESTERIO*, Claudio OSORIO-NAVARro, Madelaine \\ AZÓCAR, Charleen COPIER, Mauricio RUBILAR, LOREnA PIZARRO ${ }^{+}$, \\ JAIME AUGER \\ Departamento de Sanidad Vegetal, Facultad de Ciencias Agronómicas, Universidad de \\ Chile, Santiago, Chile \\ + Current affiliation: Instituto de Ciencias Agroalimentarias, Animales y Ambientales \\ (ICA3), Universidad de O'Higgins, Ruta $90 \mathrm{~km} \mathrm{3,} \mathrm{San} \mathrm{Fernando,} \mathrm{Chile}$ \\ ${ }^{\star}$ Corresponding author. E-mail: mesterio@uchile.cl
}

\begin{abstract}
Summary. Disease management programmes in Chilean table grape vineyards use the hydroxyanilide fenhexamid as a pivotal fungicide for Botrytis cinerea control. However, fenhexamid-resistant populations of this pathogen have progressively increased in vineyards under fungicide use. Botrytis cinerea isolates were collected in 'Thompson Seedless' vineyards under fenhexamid control programmes (>two sprays per season) from three regions of Central Chile, during the 2013-2014, 2014-2015 and 2015-2016 growing seasons. Focusing on the 2015-2016 growing season when the greatest level of resistance was measured, only $8 \%$ of recovered isolates were sensitive to fenhexamid with $92 \%$ of isolates exceeding the sensitivity threshold for mycelium growth. All fenhexamid resistant isolates analyzed carried a mutation in the Erg27 gene, which encodes for 3-keto reductase (3-KR) enzyme. The largest proportion of isolates presented a single-point mutation, leading to a substitution of phenylalanine by serine or isoleucine in the 412 residue of $3-\mathrm{KR}\left(\operatorname{erg} 27^{\mathrm{F} 412 \mathrm{~S}}, 27 \%\right.$; $\left.\operatorname{erg} 27^{\mathrm{F} 412 \mathrm{I}}, 48 \%\right)$. Substitution by valine in this position was observed in a lower proportion of isolates $\left(\operatorname{erg} 27^{\mathrm{F} 412 \mathrm{~V}}\right.$, $2 \%)$. In contrast to a previous report indicating high fitness cost in isolates carrying $\operatorname{erg} 27^{\mathrm{F} 412 \mathrm{~S}}$ or $\operatorname{erg} 27^{\mathrm{F} 412 \mathrm{I}}$, mycelium growth and sclerotia development under different restrictive temperatures were not affected compared to wildtype Erg2 $7^{\mathrm{F} 412}$ in Chilean mutant isolates. At $0^{\circ} \mathrm{C}, \operatorname{erg} 27^{\mathrm{F} 412 \mathrm{~S}}$ and $\operatorname{erg} 27^{\mathrm{F} 412 \mathrm{I}}$ generated larger lesions than $\operatorname{erg} 27^{\mathrm{F} 412 \mathrm{~V}}$ and $\operatorname{Erg} 27^{\mathrm{F} 412}$ isolates in wounded and unwounded berry assays. Another five mutations were detected in low-resistance $\operatorname{Erg} 27^{\mathrm{F} 412}$ isolates; one was a previously unreported mutation: $\operatorname{erg} 27^{\mathrm{R} 330 \mathrm{P}}$. This study has demonstrated a significant loss of sensitivity to fenhexamid, limited fitness cost and high aggressiveness levels (erg2 $7^{\mathrm{F} 412 \mathrm{~S}}$ and $\operatorname{erg} 27$ F412I) in field isolates carrying Erg27 mutations, giving dirctions for the design of Botrytis control programmes based on fenhexamid.
\end{abstract}

Keywords: Botrytis fitness cost, Erg27 mutations, resistance, increased virulence. 


\section{INTRODUCTION}

Gray mold (caused by Botrytis cinerea Pers.: Fr.) is the most economically important disease in Chilean table grape production. Botrytis cinerea infection is favoured under wet conditions with temperatures below $22^{\circ} \mathrm{C}$; it is a cool-season disease. Environmental conditions between late winter and spring in Chile usually provide the requirements for $B$. cinerea infection in the table grape growing area, causing blossom blight during the bloom period at the beginning of the season. Botrytis cinerea infections may also remain latent (Keller et al., 2003; Viret et al., 2004), leading to disease appearance after harvest either during storage or after purchase by consumers.

Control of $B$. cinerea on diverse crops is commonly achieved with combinations of pesticide and agronomic practices. Agronomic practices alone cannot prevent the disease in central Chile, so chemical treatments must be applied (Esterio et al., 2011). Because of the epidemiological traits of $B$. cinerea, disease forecasting models are not commonly used. Instead, treatments are applied at fixed phenological plant stages: bloom, bunch closure, veraison, and pre-harvest. However, more sprays may be scheduled under specific weather events that increase the risks of disease outbreaks. Among the wide range of fungicides registered for use against $B$. cinerea, fenhexamid, a hydroxyanilide derivate, has become a key component of gray mold management in Chilean table grape vineyards.

The sterol-3-ketoreductase enzyme (3-KR) encoded by the Erg27 gene is the biological target of fenhexamid. This enzyme is required for C4 demethylation during ergosterol biosynthesis (Debieu et al., 2001). Inhibition of 3-KR leads to ergosterol depletion and accumulation of cytotoxic-ergosterol precursors, triggering defects in central cellular processes (Akins, 2005). Resistance to fenhexamid in $B$. cinerea has been reported in vineyards from Europe and the United States of America (Fillinger and Walker, 2016), and is linked to several mutations in the Erg27 gene. High level of resistance occurs in isolates carrying single point mutations in codon 412 (Fillinger et al., 2008).

Since the introduction of fenhexamid in 1999, this fungicide has been widely used to $B$. cinerea control in table grape vineyards in Chile, being applied mainly during the grapevine bloom period. Fenhexamid resistance was reported in $B$. cinerea isolates from the Central Valley of Chile in the 2006-2007 growing season (Esterio et al., 2007; Esterio et al., 2011). Therefore, alternation of fungicides with different modes of action has been the strategy widely used for $B$. cinerea chemical control, in order to reduce the selection pressure.
Acquisition of high-level specific resistance to fenhexamid in $B$. cinerea has been described in isolates carrying mutation in codon 412 of Erg27, and has been associated with important decreases in pathogen fitness, including reduced conidium germination, myceliuml growth, and sclerotium development. Consequently, field problems associated with loss of efficacy of fenhexamid have not been reported to date (Ziogas et al., 2003; De Guido et al., 2007; Billard et al., 2012). In recent years, however, loss of sensitivity to fenhexamid has progressively and persistently increased in table grape fields in central Chile (Esterio et al., 2017). In order to maintain and promote fenhexamid effectiveness, the fitness cost of fenhexamid-resistance isolates from central Chile must be determined, and these should be included during construction of comprehensive and updated $B$. cinerea control programmes. For this purpose, $B$. cinerea isolates were recovered from six 'Thompson Seedless' vineyards managed with at least two fenhexamid applications per growing season to: (i) assess their sensitivity of the isolates to fenhexamid; (ii) determine their Erg27 genotype; and (iii) evaluate fitness parameters.

\section{MATERIALS AND METHODS}

\section{Botrytis cinerea isolation and culture media}

Botrytis cinerea isolates were recovered during the 2013-2014, 2014-2015 and 2015-2016 growing seasons, from grapevine flowers collected at the full bloom and berries with $16.5^{\circ}$ Brix stages, from six cv. Thompson Seedless vineyards located in the Chilean Central Valley, covering the three most important table grape production areas of Valparaíso Region (VR), Metropolitan Region (MR) and O'Higgins Region (OR). These vineyards had been undergoing field programmes with high fungicide pressure, being sprayed at least twice with fenhexamid per growing season. Botrytis cinerea singleconidium cultures isolated from these three regions were grown on malt yeast agar $\left(20 \mathrm{~g} \mathrm{~L}^{-1}\right.$ malt extract, $5 \mathrm{~g} \mathrm{~L}^{-1}$ Bacto yeast extract, $12.5 \mathrm{~g} \mathrm{~L}^{-1}$ agar) maintained at $20^{\circ} \mathrm{C}$ in constant darkness until conidiation. In total, 132 isolates from VR, 118 from MR, and 158 from OR were used in this study.

\section{Fenhexamid sensitivity assay}

Fenhexamid sensitivity was evaluated in vitro using colony growth tests. Colony growth tests were made on plates containing Sisler synthetic medium $\left(2 \mathrm{~g} \mathrm{~L}^{-1}\right.$ 
$\mathrm{KH}_{2} \mathrm{PO}_{4}, 1.5 \mathrm{~g} \mathrm{~L}^{-1} \mathrm{~K}_{2} \mathrm{HPO}_{4}, 1 \mathrm{~g} \mathrm{~L}^{-1}\left(\mathrm{NH}_{4}\right)_{2} \mathrm{SO}_{4}, 0.5 \mathrm{~g}$ $\mathrm{L}^{-1}, \mathrm{MgSO}_{4} \cdot 7 \mathrm{H}_{2} \mathrm{O}, 10 \mathrm{~g} \mathrm{~L}^{-1}$ glucose, $2 \mathrm{~g} \mathrm{~L}^{-1}$ yeast extract and $12.5 \mathrm{~g} \mathrm{~L}^{-1}$ agar) (Leroux et al., 1999) supplemented with different concentrations of fenhexamid $(0 ; 0.03 ; 0.1$; $0.3 ; 1 ; 3$ and $10 \mathrm{mg} \mathrm{L}^{-1}$ ). Four-day-old mycelium plugs were seeded on the plates, and the cultures were then kept for 5 days at $20^{\circ} \mathrm{C}$ in darkness. Colony growth was determined by measuring the diameter of the resulting colonies. Three replicate plates were analyzed for each fenhexamid concentration in colony growth experiments. $\mathrm{EC}_{50}$ values (effective inhibitory dose that gave half-maximum inhibitory responses) were calculated for each isolate using the Minitab Version 12 statistical software program.

\section{Erg27 genotyping: amplification and sequencing}

Botrytis cinerea genomic DNA was isolated from 7-day-old mycelia using the DNeasy Plant mini kit (QIAGEN). A fragment of the Erg27 gene was amplified using primers erg1800down and erg27End, which amplify a $1052 \mathrm{pb}$ fragment, previously described by Fillinger et al. (2008). The PCR mix was composed of 50-100 ng genomic DNA, 1X GoTaq Green Master Mix (Promega) and $0.2 \mu \mathrm{M}$ each primer; $25 \mu \mathrm{L}$ volume was completed with nanopure water (Promega). The PCR product was purified and used for sequencing (Macrogen). Identification of Erg27 genotypes was performed by alignment of the sequences using BioEdit software (Hall, 1999).

\section{Pathogenicity test}

To assess the pathogenicity on grape berries $B$. cinerea isolates were inoculated onto wounded and unwounded berries of 'Thompson Seedless', at harvest stage based on soluble solids content $\left(16.5^{\circ} \mathrm{Brix}\right)$. The berries were washed in $1 \%$ sodium hypochlorite solution for $0.5 \mathrm{~min}$, rinsed twice with sterile distilled water and allowed to dry under a laminar flow hood. Subsequently, a $10 \mu \mathrm{L}$ droplet of $B$. cinerea isolate suspension $\left(10^{6}\right.$ conidia $\left.\mathrm{mL}^{-1}\right)$ was inoculated on the surface of each unwounded or wounded berries. Wounding was made by puncturing each berry with a sterile needle to a depth of $2 \mathrm{~mm}$. Inoculated berries were incubated at 0 or $20^{\circ} \mathrm{C}$ in sealed humidity chambers (80\% relative humidity) for 4 days and the diameter of the gray mold lesion on each berry was measured. Eighteen berries were used for each $\operatorname{Erg} 27$ genotype separated into three replicates. The experiment was repeated twice independently, firstly using table grape berries from seasons 2016-2017 and and second from 2018-2019.
Evaluations of colony growth, conidium production and sclerotium development

Six isolates for each identified $\operatorname{Erg} 27$ genotype were used in this study, including wild type (no mutations in the $\operatorname{Erg} 27$ gene). The exception was for $\operatorname{erg} 27^{\mathrm{F} 412 \mathrm{~V}}$, where only three isolates were found. In each case, 4-days-old non-sporulating mycelium plugs grown in Potato Dextrose Agar (PDA) were transferred onto a fresh PDA plate for phenotype evaluation. Three plates were used for each genotype in two independent experimental repetitions.

Mycelium radial growth was evaluated for 4 or 5 days in continuous darkness, under three temperature conditions: 15,20 or $25^{\circ} \mathrm{C}$. Conidium production was evaluated after 17 days of continuous colonial growth in darkness at $20^{\circ} \mathrm{C}$. For each evaluation, total sporulating mycelium was recovered in a vial with $15 \mathrm{~mL}$ of sterile water, which was stirred, and conidia concentration was determined using a haematocytometer. For sclerotium development, plates were incubated for 40 days in darkness at 5 or $20^{\circ} \mathrm{C}$. Number and mass of sclerotia in each plate were recorded, and the Sclerotium Index was defined as the ratio of total number of sclerotia to total sclerotium mass per plate.

\section{Statistical analyses}

Statistical analyses were carried out using ANOVA and the Bonferroni post hoc test in InfoStat software (Di Rienzo et al., 2015).

\section{RESULTS}

\section{Sensitivity of Botrytis cinerea isolates to fenhexamid}

Sensitivity to fenhexamid of each isolate was evaluated through the mycelium growth $\mathrm{EC}_{50}$. The isolates were then classified as sensitive $\left(\mathrm{Fen}^{\mathrm{S}}\right)$ or resistant $\left(\mathrm{Fen}^{\mathrm{R}}\right)$ to fenhexamid, using the recommended cutoff value for field applications of fenhexamid $\left(0.17 \mathrm{mg} \mathrm{L}^{-1}\right.$; TeldorBayer). Thirty-six isolates were obtained from VR vineyards in the 2013-2014 season and 11\% of these were $\mathrm{Fen}^{\mathrm{S}}, 72$ isolates were obtained in 2014-2015 and 6\% were $\mathrm{Fen}^{\mathrm{S}}$, and 24 isolates were obtained in 2015-2016 and $13 \%$ were Fen ${ }^{\mathrm{S}}$ (Figure 1A, Table 1). In the 20132014, 2014-2015 and 2015-2016 seasons, 35, 36, and 47 isolates from the MR vineyards were analyzed, and $23 \%$, $25 \%$, and $0 \%$ of them were Fen ${ }^{\mathrm{s}}$ (Figure 1B, Table 1). Of the isolates from OR vineyards 40,72 , and 46 isolates were obtained in the seasons 2013-2014, 2014-2015 and 2015-2016, respectively, among them 18\%, 15\% and 19\% presented sensitivity to the fungicide (Figure 1C, Table 

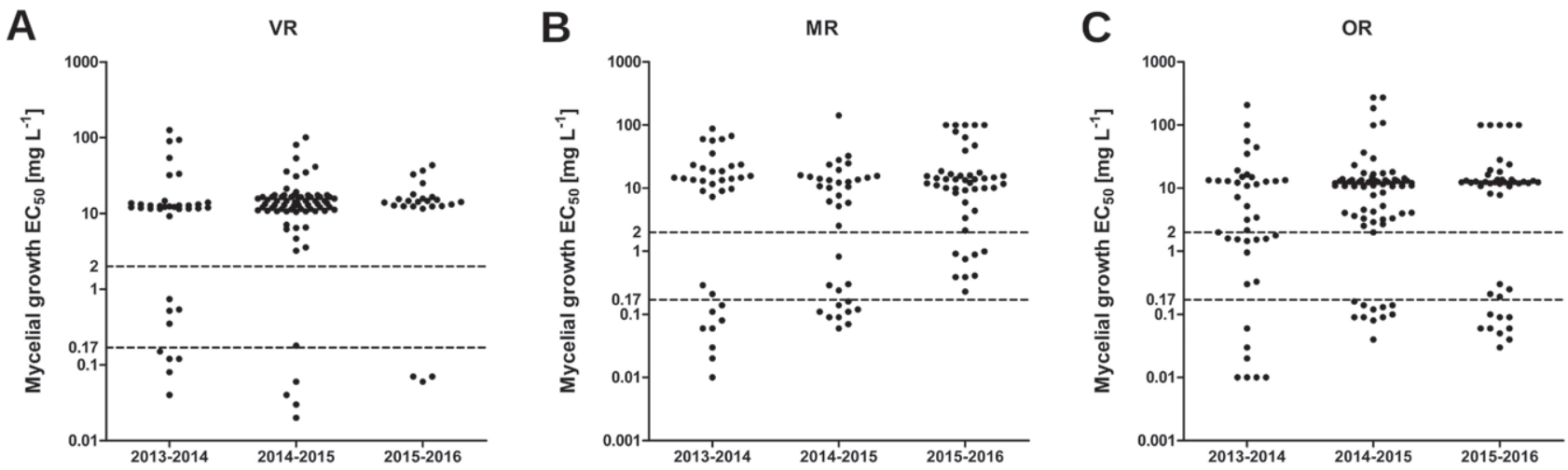

Figure 1. Sensitivity to fenhexamid of Botrytis cinera isolates obtained in the 2013-2014, 2014-2015 and 2015-2016 growing seasons from three regions of the Chilean Central Valley: Valparaíso Region (VR; $\mathrm{N}=132)$, Metropolitan Region (MR; $\mathrm{N}=118)$, and O'Higgins Region (OR; $\mathrm{N}=158)$. Fenhexamid effective concentration $\left(\mathrm{mg} \mathrm{L}^{-1}\right)$ was evaluated by $\mathrm{EC}_{50}$ value (effective concentration that reduces mycelial growth by $50 \%$ ). Isolates were considered as low resistance when $0.17 \mathrm{mg} \mathrm{L}^{-1}>\mathrm{EC}_{50} \geq 2 \mathrm{mg} \mathrm{L}^{-1}$ and high resistance when the $\mathrm{EC}_{50} \geq 2 \mathrm{mg}$ $\mathrm{L}^{-1}$; bothof these sensitivity limits are shown by dashed lines.

1). Resistance to fenhexamid was classified as low when $0.17 \mathrm{mg} \mathrm{L}^{-1}>\mathrm{EC}_{50} \geq 2 \mathrm{mg} \mathrm{L}^{-1}$ and high when $\mathrm{EC}_{50} \geq 2$ mg $\mathrm{L}^{-1}$, considering the cutoff value described by Fillinger et al. (2008). The frequency of fenhexamid-resistant and highly resistant isolates in the $B$. cinerea population analysed in this study increased with time and this occurred in the three geographical regions under study.

\section{Genetic characterization of Erg27 in Botrytis cinerea isolates}

Mutations in wild type Erg27 allele in B. cinerea isolates from the field and laboratory-generated strains have been associated with different ranges of loss of sensitivity to fenhexamid (Fillinger et al. 2008; Esterio et al. 2011; Grabke et al. 2013; Amiri and Peres, 2014). In particular, mutations in 412 codon of Erg27 trigger high resistance to this fungicide (Fillinger et al., 2008; Debieu and Leroux, 2015; Fillinger and Walker, 2016).

The Erg27 genotypes of isolates from the three regions (2015-2016 season) were evaluated in order to find a genetic factor associated with resistance to fenhexamid. Of a total of 24 isolates from the VR region, $29 \%$ carried a serine substitution $\left(\operatorname{erg} 27^{\mathrm{F} 412 \mathrm{~S}}\right)$ and $58 \%$ the isoleucine substitution (erg2 $7^{\mathrm{F} 412 \mathrm{I}}$ ) at position 412 , and only $13 \%$ of total isolates maintained phenylalanine at the 412

Table 1. Sensitivity to fenhexamid of Botrytis cinerea isolates from Central Chile, from Valparaíso Region (VR), Metropolitan Region (MR) and O'Higgins Region (OR).

\begin{tabular}{|c|c|c|c|c|c|c|c|c|}
\hline Region & Season & Total isolates & $\% \mathrm{~S}^{\mathrm{a}}$ & $\% \mathrm{LR}^{\mathrm{b}}$ & $\% \mathrm{HR}^{\mathrm{c}}$ & $\begin{array}{l}\text { Mean } \\
E C_{50}{ }^{d}\end{array}$ & $\operatorname{Min} E C_{50}^{e}$ & $\operatorname{Max} E C_{50} f$ \\
\hline \multirow{3}{*}{ VR } & $2013-14$ & 36 & 11.11 & 11.11 & 77.78 & 19.16 & 0.04 & 125.50 \\
\hline & 2014-15 & 72 & 5.56 & 1.39 & 93.05 & 16.19 & 0.02 & 100.70 \\
\hline & $2015-16$ & 24 & 12.50 & 0.00 & 87.50 & 15.73 & 0.06 & 43.26 \\
\hline \multirow{3}{*}{ MR } & $2013-14$ & 35 & 22.86 & 5.71 & 71.43 & 18.67 & 0.01 & 87.08 \\
\hline & $2014-15$ & 36 & 25.00 & 11.11 & 63.89 & 12.75 & 0.06 & 142.30 \\
\hline & $2015-16$ & 47 & 0.00 & 17.39 & 82.61 & 23.43 & 0.23 & 100.00 \\
\hline \multirow{3}{*}{ OR } & 2013-14 & 40 & 17.50 & 22.50 & 60.00 & 16.41 & 0.01 & 208.10 \\
\hline & $2014-15$ & 72 & 15.28 & 1.39 & 83.33 & 21.80 & 0.04 & 273.60 \\
\hline & $2015-16$ & 46 & 19.15 & 8.51 & 72.34 & 19.05 & 0.03 & 100.00 \\
\hline
\end{tabular}

${ }^{\text {a }}$ Frequency occurrence (\%) of sensitive isolates $\left(\mathrm{EC}_{50}<0.17 \mathrm{mg} \mathrm{L}^{-1}\right)$.

${ }^{\mathrm{b}}$ Frequency occurrence (\%) of low-resistant isolates $\left(0.17 \mathrm{mg} \mathrm{L}^{-1}<\mathrm{EC}_{50} \leq 2.0 \mathrm{mg} \mathrm{L}^{-1}\right)$.

${ }^{c}$ Frequency occurrence (\%) of high-resistant isolates $\left(\mathrm{EC}_{50}>2.0 \mathrm{mg} \mathrm{L}^{-1}\right)$.

${ }^{\mathrm{d}}$ Mean $\mathrm{EC}_{50}\left(\mathrm{mg} \mathrm{L}^{-1}\right)$.

${ }^{e}$ Minimum value of $\mathrm{EC}_{50}\left(\mathrm{mg} \mathrm{L}^{-1}\right)$.

${ }^{\mathrm{f}}$ Maximum value of $\mathrm{EC}_{50}\left(\mathrm{mg} \mathrm{L}^{-1}\right)$. 


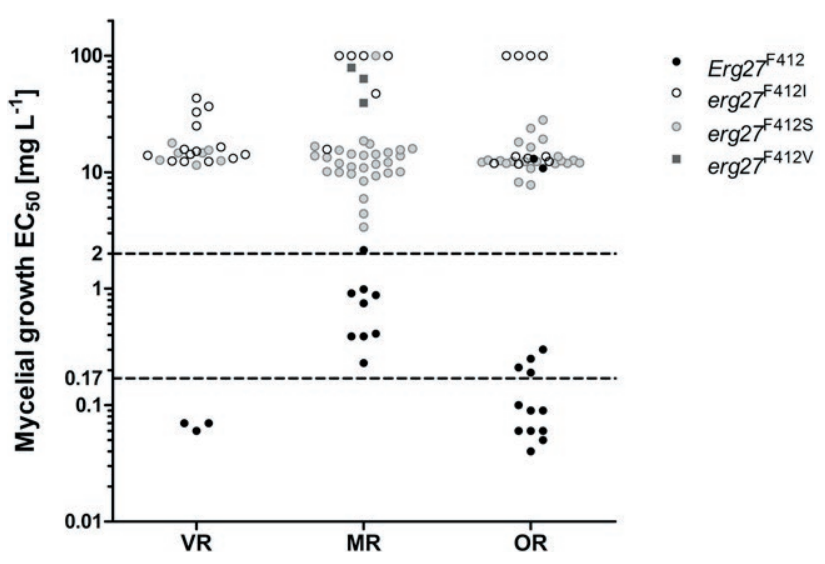

Figure 2. Fenhexamid sensitivity levels of Botrytis cinerea isolates carrying a mutation $\operatorname{Erg} 27^{\mathrm{F} 412}$ from Valparaíso Region (VR; $\mathrm{N}=2$ 4), Metropolitan Region (MR; N = 47) and O'Higgins Region (OR; $\mathrm{N}=46$ ) in the 2015-2016 growing season, based on $\mathrm{EC}_{50}$ values (effective concentration that reduced mycelium growth by $50 \%$ ). Sensitivity limits are shown by dashed lines: low resistance $=0.17$ $\mathrm{mg} \mathrm{L}^{-1}>\mathrm{EC}_{50} \geq 2 \mathrm{mg} \mathrm{L}^{-1}$ and high resistance $=\mathrm{EC}_{50} \geq 2 \mathrm{mg} \mathrm{L}^{-1}$.

position $\left(\operatorname{Erg} 27^{\mathrm{F} 412}\right)$ (Table 2, Figure 2). As expected, all isolates from this region carrying the mutations in the 412 position of $\operatorname{Erg} 27$ were highly resistant to fenhexamid, and the isolates without mutation in this codon were fenhexamid sensitive. From the MR region, 47 isolates were tested. Substitutions $\operatorname{erg} 27^{\mathrm{F} 412 \mathrm{~S}}$ was at frequency of $62 \%$, and $\operatorname{erg} 27^{\mathrm{F} 412 \mathrm{I}}$ at $13 \%$, while $19 \%$ of the isolates had no mutation in $\operatorname{Erg}_{27} 7^{\mathrm{F} 412}$ (Table 1, Figure 2). Three isolates $(6 \%)$ carried a non-common mutation of valine instead phenylalanine at 412 position $\left(\operatorname{erg} 27^{\mathrm{F} 412 \mathrm{~V}}\right.$, 6\%) (Table 1, Figure 2). All the highly resistant isolates in this population had mutations in codon 412 of Erg27, as expected. However, nine isolates with no mutation in $\operatorname{Erg} 27^{\mathrm{F} 412}$ showed some resistance to fenhexamid, suggesting that mutations in other positions of Erg27 or on another gene could be responsible for the resistance.

In the 46 isolates from OR, $48 \%$ carried the $\operatorname{erg} 27^{\mathrm{F} 4125}$ mutation and $22 \%$ the $\operatorname{erg} 27^{\mathrm{F} 412 \mathrm{I}}$ mutation, exhibiting high resistance to fenhexamide (Table 1, Figure 2). In this case, $30 \%$ of the isolates had no mutation at $\operatorname{Erg27} 7^{\mathrm{F} 12}$; two of these isolates showed high resistance to the fungicide and four had low resistance.

The low and high resistance in isolates from the MR and OR regions that lacked mutations in $\operatorname{Erg} 27^{\mathrm{F} 412}$ raised the possibility of another codon of Erg27 being mutated and conferring resistance to fenhexamid. To answer this, the sequence of the $\operatorname{Erg} 27$ gene was scrutinized to identify other mutations. Five other mutations were found in the $\operatorname{Erg} 27$ gene, including $\operatorname{erg} 27^{\mathrm{L} 195 \mathrm{~F}}$, $\operatorname{erg} 27^{\mathrm{P} 238 \mathrm{~S}}, \operatorname{erg} 27^{\perp 298}$, $\operatorname{erg} 27^{\mathrm{R} 330 \mathrm{P}}$ and $\operatorname{erg} 27^{\mathrm{N} 369 \mathrm{D}}$. These mutations were found in different combinations, in the 117 isolates analyzed from
Table 2. Numbers of Botrytis cinerea isolates of Erg27 genotype at the 412 position, obtained from Central Chile, from Valparaíso Region (VR), Metropolitan Region (MR) and O'Higgins Region (OR).

\begin{tabular}{|c|c|c|c|c|c|c|c|c|c|}
\hline \multirow[b]{2}{*}{ Region } & \multirow{2}{*}{$\begin{array}{c}\text { Total } \\
\text { isolates }\end{array}$} & \multicolumn{2}{|c|}{$\operatorname{Erg} 27^{\mathrm{F} 412}$} & \multicolumn{2}{|c|}{$\operatorname{erg} 27^{\mathrm{F} 412 \mathrm{I}}$} & \multicolumn{2}{|c|}{$\operatorname{erg} 27^{\mathrm{F} 412 \mathrm{~S}}$} & \multicolumn{2}{|c|}{$\operatorname{erg} 27^{\mathrm{F} 412 \mathrm{~V}}$} \\
\hline & & $\%^{\mathrm{a}}$ & $\begin{array}{l}\text { Mean } \\
\mathrm{EC}_{50}{ }^{\mathrm{b}}\end{array}$ & $\%^{a}$ & $\begin{array}{l}\text { Mean } \\
\mathrm{EC}_{50}{ }^{\mathrm{b}}\end{array}$ & $\%^{a}$ & $\begin{array}{l}\text { Mean } \\
\mathrm{EC}_{50} \mathrm{~b}\end{array}$ & $\%^{a}$ & $\begin{array}{l}\text { Mean } \\
\mathrm{EC}_{50}{ }^{\mathrm{b}}\end{array}$ \\
\hline $\mathrm{R}$ & 2 & 13 & 0.0 & 58 & 19.85 & 29 & 14. & - & - \\
\hline IR & 47 & 19 & 0.79 & 13 & 77.18 & 62 & 17.90 & 6 & 60.5 \\
\hline DR & 46 & 30 & 1.81 & 22 & 47.65 & 48 & 13.90 & - & - \\
\hline
\end{tabular}

${ }^{a}$ Frequency occurrence of genotype in percentage

${ }^{\mathrm{b}}$ Mean $\mathrm{EC}_{50}\left(\mathrm{mg} \mathrm{L}^{-1}\right)$ for genotype of $\operatorname{Erg} 27$ at the 412 position.

the three regions. $\operatorname{erg} 27^{\mathrm{P} 238 \mathrm{~S}}, \operatorname{erg} 27^{\mathrm{L} 195 \mathrm{~F} / \Delta 298}$ and $\operatorname{erg} 27^{\Delta 298 /}$ ${ }_{\mathrm{R} 330 \mathrm{P}}$ were present in isolates that lacked mutation in position 412 of $\operatorname{Erg} 27$ and were resistant to fenhexamid (Figure $3 \mathrm{~A}$ ), suggesting that these mutations could lead to resistance to fenhexamide. However, $\operatorname{erg} 27^{\Delta 298}$ by itself possibly did not affect resistance to this fungicide. Similarly, erg27 $7^{\mathrm{N} 369 \mathrm{D}}$ combined with $\operatorname{erg} 27^{\mathrm{P} 238 \mathrm{~F} / \mathrm{N} 369 \mathrm{D}}$ did not give resistance to fenhexamid, although $\operatorname{erg} 27^{\mathrm{P} 2385}$ by itself correlated with fenhexamid resistance. Mutations in other positions were also detected in the isolates carrying erg2 $7^{\mathrm{F} 412 \mathrm{~S}}$ or erg2 $7^{\mathrm{F} 412 \mathrm{I}}$ (Figure 3B-D). However clear correlations between their presence and fenhexamid resistance were not detected, indicating that mutations in position 412 are more relevant for fenhexamid resistance.

Evaluation of growth parameters and virulence of the Botrytis cinerea isolates carrying mutations in Erg27

Growth parameters and virulence were analyzed to evaluate the performance of fenhxamid resistant isolates from VR, OR, and MR carrying mutations in the 412 position of the Erg27 gene. Mycelium growth was evaluated under suboptimal $\left(15^{\circ} \mathrm{C}\right)$ and optimal temperature conditions $\left(20\right.$ or $\left.25^{\circ} \mathrm{C}\right)$. No differences in mycelium radial growth were observed among field isolates with non-mutated $\operatorname{Erg} 27^{\mathrm{F} 412}$ and $\operatorname{erg} 27^{\mathrm{F} 412 \mathrm{~S}}$, $\operatorname{erg} 27^{\mathrm{F} 412 \mathrm{I}}$ or $\operatorname{erg}$ $27^{\mathrm{F} 412 \mathrm{~V}}$ at the three growing temperature tested (Figure $4 \mathrm{~A}, 4 \mathrm{~B}$ and $4 \mathrm{C}$ ).

Development of sclerotia as survival structures is essential for overwintering of $B$. cinerea inoculum in the field. Therefore, sclerotium development was evaluated in two contrasting temperature conditions: 5 or $20^{\circ} \mathrm{C}$. Numbers of sclerotia, sclerotia masses and sclerotia indices (ratio of numbers to masses) were quantified. No statistically significant differences were observed between $\operatorname{Erg} 27^{\mathrm{F} 412}, \operatorname{erg} 27^{\mathrm{F} 412 \mathrm{~S}}$ or $\operatorname{erg} 27^{\mathrm{F} 412 \mathrm{I}}$ at $5^{\circ} \mathrm{C}$, but at this temperature, the restriction of sclerotium develop- 

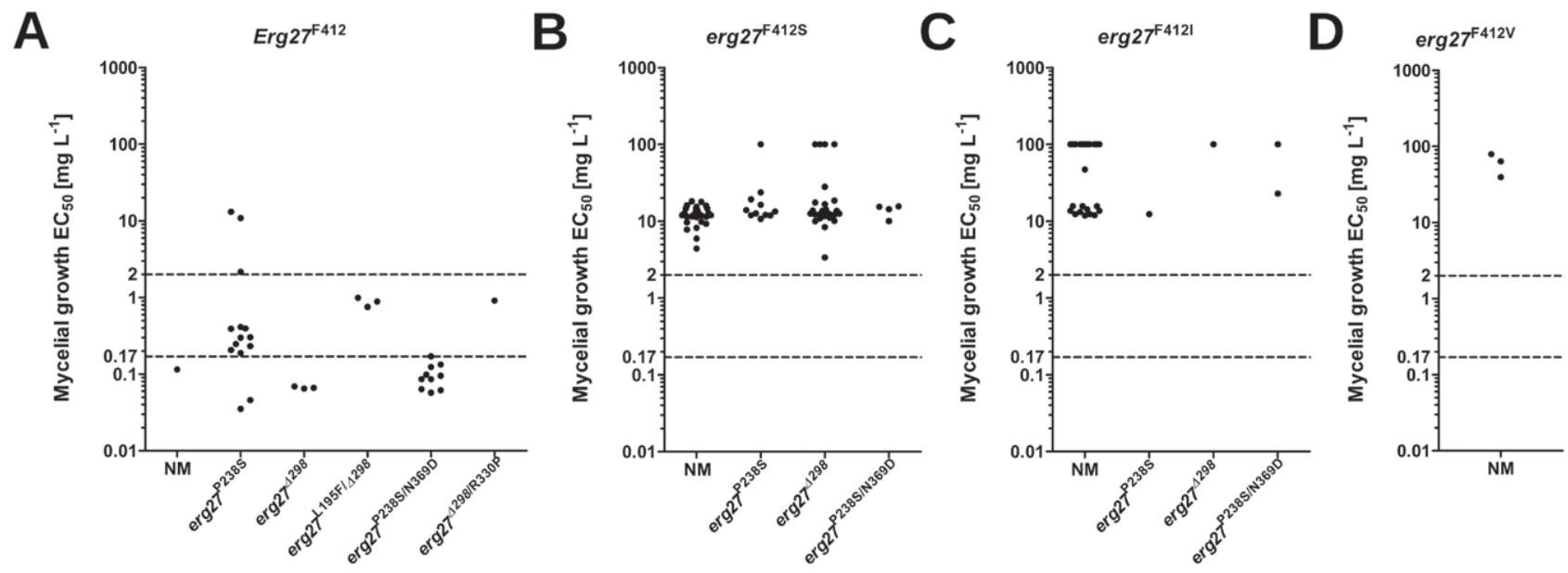

Figure 3. Sensitivity to fenhexamid in Botrytis cinerea isolates $\operatorname{Erg} 27^{\mathrm{F} 412}$ (A), $\operatorname{erg} 27^{\mathrm{F} 412 \mathrm{~S}}$ (B), $\operatorname{erg} 27^{\mathrm{F} 412 \mathrm{I}}$ (C) and $\operatorname{erg} 27^{\mathrm{F} 412 \mathrm{~V}}$ (D) carrying additional mutations is shown based on $\mathrm{EC}_{50}$ values (effective concentration that reduces mycelium growth by $50 \%$ ). Five other mutations were detected: $\operatorname{erg} 27^{\mathrm{L} 195 \mathrm{~F}}, \operatorname{erg} 27^{\mathrm{P} 238 \mathrm{~S}}, \operatorname{erg} 27^{\Delta 298}, \operatorname{erg} 27^{\mathrm{R} 330 \mathrm{P}}$ and $\operatorname{erg} 27^{\mathrm{N} 369 \mathrm{D}}$. Dashed lines indicate sensitivity limits: low resistance $=0.17 \mathrm{mg} \mathrm{L}^{-1}>$ $\mathrm{EC}_{50} \geq 2 \mathrm{mg} \mathrm{L}^{-1}$ and high resistance $=\mathrm{EC}_{50} \geq 2 \mathrm{mg} \mathrm{L}^{-1}$.

A

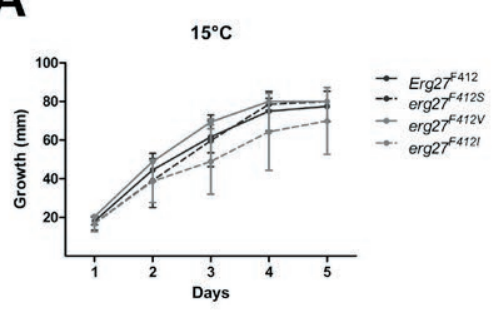

B

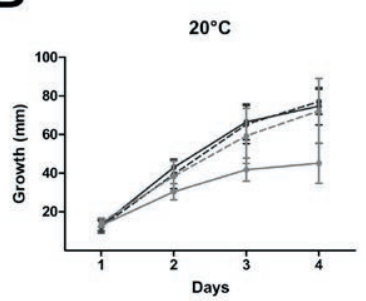

C

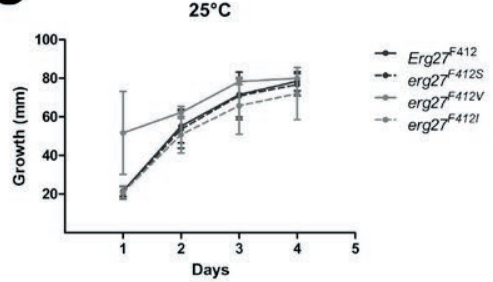

D

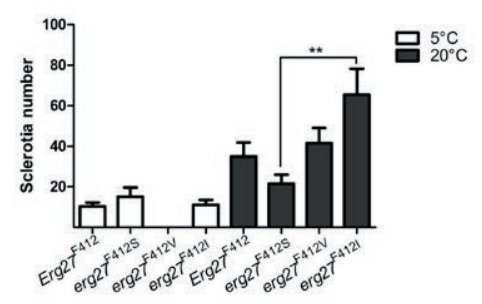

E

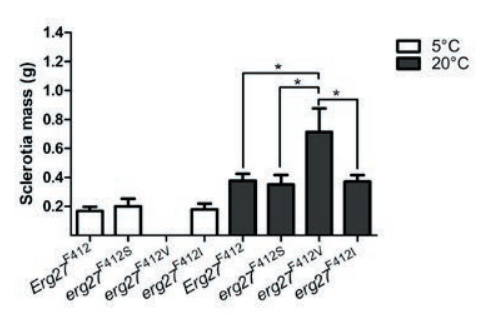

F

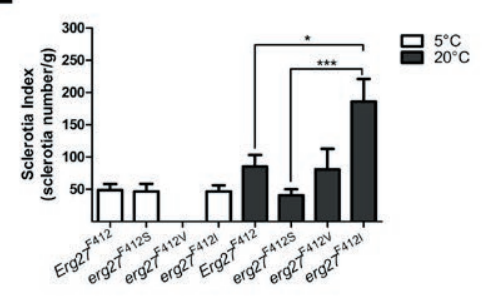

G

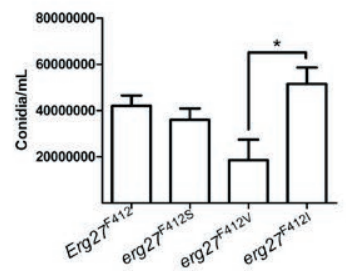

H

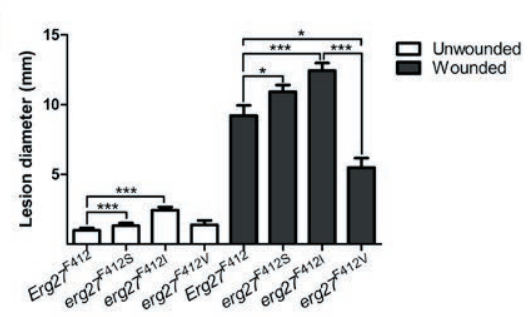

I

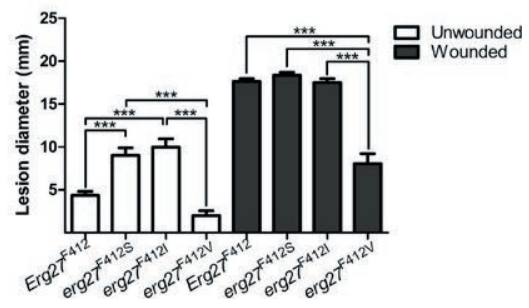

Figura 4. Comparation on fitness parameters between $\operatorname{Erg} 27^{\mathrm{F} 412}$, $\operatorname{erg} 27^{\mathrm{F} 412 \mathrm{~S}}$, $\operatorname{erg} 27^{\mathrm{F} 412 \mathrm{I}}$ and $\operatorname{erg} 27^{\mathrm{F} 412 \mathrm{~V}}$ isolates of Botrytis cinerea. Radial mycelium growth was evaluated at $15^{\circ} \mathrm{C}(\mathrm{A}), 20^{\circ} \mathrm{C}(\mathrm{B})$ or $25^{\circ} \mathrm{C}(\mathrm{C})$. Sclerotium development was measured using numbers of sclerotia (D), sclerotium mass (E) and Sclerotia Index (F), evaluated at $5^{\circ} \mathrm{C}$ or $20^{\circ} \mathrm{C}$. Conidium production was also evaluated (G). Wounded and Unwounded detached table grape berries were used to evaluate aggressiveness levels at 0 or $20^{\circ} \mathrm{C}$ in $\operatorname{Erg} 27$ mutant isolates (H, I). Asterisks indicate significant differences $\left({ }^{*} P<0.05 ;{ }^{* *} P<0.01 ;{ }^{* * *} P<0.001\right)$ 
ment did not occur with $\operatorname{erg} 27^{\mathrm{F} 412 \mathrm{~V}}$ isolates (Figur $4 \mathrm{D}, 4 \mathrm{E}$ and $4 \mathrm{~F}$ ). At $20^{\circ} \mathrm{C}, \operatorname{erg} 27^{\mathrm{F} 412 \mathrm{~S}}$ produced fewer of sclerotia than $\operatorname{erg} 27^{\mathrm{F} 412 \mathrm{I}}$, but equivalent numbers to $\operatorname{Erg} 27^{\mathrm{F} 412}$ and $\operatorname{erg} 27^{\mathrm{F} 412 \mathrm{~V}}$ (Figure 4D). The sclerotium mass was greater in $\operatorname{erg} 27^{\mathrm{F} 412 \mathrm{~V}}$ compared to other isolates carrying mutant alleles (Figure 4E). Evaluation of the sclerotium indices showed greater values in strains carrying $\operatorname{erg} 7^{\mathrm{F} 412 \mathrm{I}}$ (Figure $4 \mathrm{~F}$ ).

Conidium production was investigated to establish the propagation capacity of isolates carrying different Erg27 mutations at optimal temperature for B. cinerea development. No differences in conidium production were observed between $\operatorname{erg} 27^{\mathrm{F} 412 \mathrm{~S}}, \operatorname{erg} 27^{\mathrm{F} 412 \mathrm{I}}$ and isolates carrying the wild type Erg27. However, significantly fewer conidia were produced by erg2 $7^{\mathrm{F} 412 \mathrm{~V}}$ isolates (Figure $4 \mathrm{G})$, indicating that this mutation impaired conidium development.

The infection capacity of the Erg27 mutants was measured on detached 'Thompson Seedless' grape berries using six isolates of each genotype. On unwounded berries incubated at $0^{\circ} \mathrm{C}$, $\operatorname{erg} 27^{\mathrm{F} 412 \mathrm{I}}$ isolates developed larger rot lesions than berries inoculated with $\operatorname{Erg}_{2} 7^{\mathrm{F} 412}$, $\operatorname{erg} 27^{\mathrm{F} 412 \mathrm{~S}}$ or $\operatorname{erg} 27^{\mathrm{F} 412 \mathrm{~V}}$ isolates. In wounded berries, $\operatorname{erg} 27^{\mathrm{F} 412 \mathrm{~S}}$ and $\operatorname{erg} 27^{\mathrm{F} 412 \mathrm{I}}$ generated larger lesions compared to the $\operatorname{Erg} 27^{\mathrm{F} 412}$ genotype, while $\operatorname{erg} 27^{\mathrm{F} 412 \mathrm{~V}}$ produced smaller lesions than the $\operatorname{Erg} 27^{\mathrm{F} 412}$ genotype isolates (Figure $4 \mathrm{H}$ ). At $20^{\circ} \mathrm{C}$, unwounded berries inoculated with $\operatorname{erg} 27^{\mathrm{F} 412 \mathrm{I}}$ or $\operatorname{erg} 27^{\mathrm{F} 412 \mathrm{~S}}$ isolates developed enhanced infection damage compared with $\mathrm{Erg} 27^{\mathrm{F} 412}$. However, the necrotic damage observed in wounded berries infected by $\operatorname{erg} 27^{\mathrm{F} 412 \mathrm{~S}}$ or $\operatorname{erg} 27^{\mathrm{F} 412 \mathrm{I}}$ did not differ from that caused by $\operatorname{Erg} 27^{\mathrm{F} 412}$ isolates. In contrast, $\operatorname{erg} 27^{\mathrm{F} 412 \mathrm{~V}}$ isolates were less aggressive than $\mathrm{Erg} 27^{\mathrm{F} 412}$ isolates in both unwounded and wounded berries (Figure $4 \mathrm{I})$. Together, these results indicate that growth in the $\operatorname{erg} 27^{\mathrm{F} 412 \mathrm{~S}}, \operatorname{erg} 27^{\mathrm{F} 412 \mathrm{I}}$ and $\operatorname{erg} 27^{\mathrm{F} 412 \mathrm{~V}}$ isolates was not affected, although they carried a mutation in Erg27, and isolates carrying $\operatorname{erg} 27^{\mathrm{F} 412 \mathrm{~S}}$ and $\operatorname{erg} 27^{\mathrm{F} 412 \mathrm{I}}$ were of increased aggressiveness on both unwounded and wounded berries.

\section{DISCUSSION}

Table grape vines are cultivated mostly in the Central Valley of Chile because this region has favorable agroecological conditions for grape production. Grape vineyards in Chile are threatened by Botrytis outbreaks due to the frequent cool springs and wet weather conditions. Therefore, fungicides are commonly applied to vineyards in this region. Development of resistance to fungicides has been observed in B. cinerea in this area, endangering the ability to control gray mold (Latorre et al., 2015; Esterio et al., 2017).

In the present study $B$. cinerea populations collected from 'Thompson Seedless' table grape vineyards from three regions of Central Chile were shown to have reduced sensitivity to fenhexamid. This reduced sensitivity increased progressively in the the three successive growing seasons tested. Nevertheless, fenhexamid is still one of the main fungicides regularly used in the local $B$. cinerea control programmes, with at least two applications of this chemical in each growing season.

Botrytis cinerea resistant isolates to fungicides with unisite modes of action have been widely reported in the last 10 years, after intensive application programmes, accompanied by reduced fungicide efficacy (van den Bosch et al. 2015; Fillinger and Walker, 2016). The Erg27 mutation in position 412 is one of the most common changes linked to fenhexamid resistance (Fillinger et al., 2008; Billard et al., 2012; Debieu and Leroux, 2015). We reported isolates carrying $\operatorname{erg} 27^{\mathrm{F} 412 \mathrm{~S}}$, $\operatorname{erg} 27^{\mathrm{F} 412 \mathrm{I}}$ and $\operatorname{erg}$ $27^{\mathrm{F} 412 \mathrm{~V}}$ mutations; these have been previously reported in B. cinerea isolated from fields in France, Germany and the United States of America, and have been associated with high fenhexamid-resistance levels (Grabke et al., 2013; Amiri and Peres, 2014; Rupp et al., 2017). Isolates carrying mutant versions of Erg27 were predominant, including $\operatorname{erg} 27^{\mathrm{F} 412 \mathrm{I}}$ from $\mathrm{VR}$ and $\operatorname{erg} 27^{\mathrm{F} 412 \mathrm{~S}}$ from MR and OR. Strong correlations were observed between the presence of mutations at codon 412 of $\operatorname{Erg} 27$ and high resistance to fenhexamid $\left(\mathrm{EC}_{50} \geq 2 \mathrm{mg} \mathrm{L}^{-1}\right)$. The erg$27^{\mathrm{F} 412 \mathrm{I}}$ and $\operatorname{erg} 27^{\mathrm{F} 412 \mathrm{~V}}$ genotypes showed the greatest $\mathrm{EC}_{50}$ values in each population, while $\operatorname{erg} 27^{\mathrm{F} 412 \mathrm{~S}}$ presented the lowest $\mathrm{EC}_{50}$ among the mutants. This indicates that this mutation conferred less resistance to fenhexamid. In all the Chilean regions analyzed in this study, progressive increases of the resistant isolates were detected over the three growing seasons assessed, demonstrating the effects of constant fungicide pressure on $B$. cinerea population.

In addition to high fenhexamid resistance related to mutation in Erg27, particularly in the 412 position, we detected other mutations that produced moderate levels of resistance in other $\operatorname{Erg} 27$ codons: $\operatorname{erg} 27^{\mathrm{P} 238 \mathrm{~S}}, \operatorname{erg} 27^{\mathrm{L} 195 \mathrm{~F} /}$ ${ }^{\Delta 298}$ and $\operatorname{erg} 27^{\Delta 298 / \mathrm{R} 330 \mathrm{P}}$. Isolates carrying mutations $\operatorname{erg} 27^{\mathrm{L} 195 \mathrm{~F}}$ and $\operatorname{erg} 27^{\mathrm{R} 330 \mathrm{P}}$ are the first reported in Chile. Particularly, $\operatorname{erg} 27^{\mathrm{R} 330 \mathrm{P}}$ associated with moderate resistance to fenhexamid has not been previously reported (Debieu and Leroux, 2015). The presence of erg27 $2328 \mathrm{~S}$ and $\operatorname{erg} 27^{\mathrm{N} 369 \mathrm{D}}$ together suppressed resistance to fenhexamid more than in isolates carrying $\operatorname{erg} 27^{\mathrm{P} 238 \mathrm{~S}}$ alone. However, the level of resistance to fenhexamid remained unchanged in strains $\operatorname{erg} 27^{\mathrm{F} 412 \mathrm{~S}}$ and $\operatorname{erg} 27^{\mathrm{F} 412 \mathrm{I}}$ when 
$\operatorname{erg} 27^{\mathrm{N} 369 \mathrm{D}}$ was also present, suggesting that changes close to the $3-\mathrm{KR}$ transmembrane domain were more relevant in the interaction between fenhexamid and 3-KR. Our data also suggest that the presence of $\operatorname{erg} 27^{\mathrm{F} 412 \mathrm{~S}}$ produced a second functional change within the Erg27 sequence, in contrast to $\operatorname{erg} 27^{\mathrm{F} 412 \mathrm{I}}$ and $\operatorname{erg} 27^{\mathrm{F} 412 \mathrm{~V}}$.

Mutations in position 412 of Erg27 have been previously reported to reduce isolate performance (Billard et al. 2012). However, the isolates $\operatorname{erg} 27^{\mathrm{F} 412 \mathrm{I}}$ and $\operatorname{erg} 27^{\mathrm{F} 412 \mathrm{~S}}$, identified in the present study grew similarly to fenhexamid-sensitive strains at $15^{\circ} \mathrm{C}, 20^{\circ} \mathrm{C}$ and $25^{\circ} \mathrm{C}$. Sclerotium development and conidium production were also not affected in $\operatorname{erg} 27^{\mathrm{F} 412 \mathrm{I}}$ and $\operatorname{erg} 27^{\mathrm{F} 412 \mathrm{~S}}$ isolates, in contrast to previous reports that showed growth retardation in fenhexamid-resistant strains (Billard et al., 2012; Saito et al., 2014). $\operatorname{erg} 27^{\mathrm{F} 412 \mathrm{I}}$ and $\operatorname{erg} 27^{\mathrm{F} 412 \mathrm{~S}}$ B. cinerea isolates were more pathogenic, particularly in unwounded grape berries at all the temperatures tested. It is possible that the low effects on fitness and the increase in infection capacity observed in $\operatorname{erg} 27^{\mathrm{F} 412 \mathrm{I}}$ and $\operatorname{erg} 27^{\mathrm{F} 412 \mathrm{~S}}$ were due to accumulation of additional mutations that conferred adaptive advantages for survival under high fungicide selection pressure (Ishii, 2015), overcoming the negative effect reported in strains carrying $\operatorname{erg} 27^{\mathrm{F} 412 \mathrm{I}}$ and $\operatorname{erg} 27^{\mathrm{F} 412 \mathrm{~S}}$ (Billard et al., 2012). Isolates carrying erg $27^{\mathrm{F} 412 \mathrm{~V}}$ exhibited fitness costs, producing few conidia and possessing only minor increases in infection capacity. This suggests that this mutation may be rare in the field $B$. cinerea populations, being found only three times in isolates obtained in the present study.

Amino-pyrazolinone fenpyrazamine was recently introduced as a Botryticide for gray mold control in Chile. Fenpyrazamine, like fenhexamid, targets 3-KR (Kimura et al., 2017), but Erg27 changes associated with resistance to fenpyrazamine have not been studied. Fenpyrazamine could potentially control fenhexamid-resistant isolates by inhibiting $3-\mathrm{KR}$, targeting the enzyme independently of the amino-acid at position 412. Therefore, experiments determining fenpyrazamine efficacy on fenhexamid-resistant isolates are required, to provide a basis for restructuring chemical control strategies to reduce occurrence of highly resistant $B$. cinerea populations.

The present research has highlighted the prevalence of fenhexamid resistance linked to the Erg27 genotype in B. cinera populations isolated from 'Thompson Seedless' vineyards treated with this fungicide in the Central Valley of Chile. These results show an overall reduction of fitness in fenehxamid-resistant B. cinera isolates, suggesting the appearance of adapted strains resistant to this fungicide. This poses serious risks for field control of gray mold in table grape production in Chile.

\section{ACKNOWLEDGEMENTS}

This research was financially supported by Grant FIA PYT-2016-0243. We thank Veronica Estrada for technical support.

\section{LITERATURE CITED}

Amiri A., Peres N.A., 2014. Diversity in the erg27 Gene of Botrytis cinerea field isolates from strawberry defines different levels of resistance to the hydroxyanilide fenhexamid. Plant Disease 98(8): 1131-1137.

Akins R.A., 2005. An update on antifungal targets and mechanisms of resistance in Candida albicans. Medical Mycology 43(4): 285-318.

Billard A., Fillinger S., Leroux P., Lachaise H., Beffa R., Debieu D., 2012. Strong resistance to the fungicide fenhexamid entails a fitness cost in Botrytis cinerea, as shown by comparisons of isogenic strains. Pest Management Science 68(5): 684-691.

Debieu D., Bach J., Hugon M., Malosse C., Leroux P., 2001. The hydroxyanilide fenhexamid, a new sterol biosynthesis inhibitor fungicide efficient against the plant pathogenic fungus Botryotinia fuckeliana (Botrytis cinerea). Pest Management Science 57(11): 10601067.

Debieu D., Leroux P., 2015. Sterol Biosynthesis Inhibitors: C-4 Demethylation. In: Fungicide Resistance in Plant Pathogens (H. Ishii, D.W. Hollomon, ed.) Springer, Japan, 217-232.

De Guido M.A., De Miccolis Angelini R.M., Pollastro S., Santomauro A., Faretra F., 2007. Selection and genetic analysis of laboratory mutants of Botryotinia fuckeliana resistant to fenhexamid. Journal of Plant Pathology 89: 203-210.

Di Rienzo J.A., Casanoves F., Balzarini M.G., González L., Tablada M., Robledo C.W., 2015. InfoStat. InfoStat Group, FCA, Universidad Nacional de Córdoba,

Argentina. http://www.infostat.com.ar

Esterio M., Auger J., Ramos C., García H., 2007. First report of fenhexamid resistant isolates of Botrytis cinerea on grapevine in Chile. Plant Disease 91(6): 768.

Esterio M., Muñoz G., Ramos C., Cofré G., Estévez R., ... Auger J., 2011. Characterization of Botrytis cinerea isolates present in Thompson Seedless table grapes in the Central Valley of Chile. Plant Disease 95(6): 683-690.

Esterio M., Copier C., Román A., Araneda M.J., Rubilar M., ... Auger J., 2017. Frequency of fungicideresistant Botrytis cinerea populations isolated from 
'Thompson Seedless' table grapes in the Central Valley of Chile. Ciencia e Investigación Agraria 44(3): 295-306.

Fillinger S., Leroux P., Auclair C., Barreau C., Al Hajj C., Debieu D., 2008. Genetic analysis of fenhexamidresistant field isolates of the phytopathogenic fungus Botrytis cinerea. Antimicrobial Agents and Chemotherapy 52 (11): 3933-3940.

Fillinger S., Walker A.S., 2016. Chemical Control and Resistance Management of Botrytis Diseases. In: Botrytis - the Fungus, the Pathogen and its Management in Agricultural Systems (S. Fillinger, Y. Elad, ed.) Springer, Switzerland, 189-216.

Grabke A., Fernández-Ortuño D., Schnabel G., 2013. Fenhexamid resistance in Botrytis cinerea from strawberry fields in the Carolinas is associated with four target gene mutations. Plant Disease 97(2): 271276.

Hall T.A., 1999. BioEdit: a user-friendly biological sequence alignment editor and analysis program for Windows 95/98/NT. Nucleic Acids Symposium Series 41: 95-98.

Ishii H., 2015. Stability of Resistance. In: Fungicide Resistance in Plant Pathogens (H. Ishii, D.W. Hollomon, ed.) Springer, Japan, 35-48.

Keller M., Viret O., Cole M., 2003. Botrytis cinerea infection in grape flowers: defence reaction, latency and disease expression. Phytopathology 93: 316-322.

Kimura N., Hashizume M., Kusaba T., Tanaka S., 2017. Development of the novel fungicide fenpyrazamine. Journal of Pesticide Science 42(3): 137-143.

Latorre B.A., Elfar K., Ferrada E.E., 2015. Gray mold caused by Botrytis cinerea limits grape production in Chile. Ciencia e Investigación Agraria 42(3): 305330.

Leroux P., Chapeland F., Desbrosses D., Gredt M., 1999. Patterns of cross-resistance to fungicides in Botryotinia fuckeliana (Botrytis cinerea) isolates from French vineyards. Crop Protection 18: 687-697.

Rupp S., Weber R.W., Rieger D., Detzel P., Hahn M., 2017. Spread of Botrytis cinerea strains with multiple fungicide resistance in German horticulture. Frontiers in Microbiology 7: 2075.

Saito S., Cadle-Davidson L., Wilcox W.F., 2014. Selection, fitness, and control of grape isolates of Botrytis cinerea variably sensitive to fenhexamid. Plant Disease 98(2): 233-240.

van den Bosch F., Paveley N., Fraaije B., van den Berg F., Oliver R., 2015. Evidence-Based Resistance Management: A Review of Existing Evidence. In: Fungicide Resistance in Plant Pathogens (H. Ishii, D.W. Hollomon, ed.) Springer, Japan, 63-76.
Viret O., Keller M., Jaudzems V.G., Cole F.M., 2004. Botrytis cinerea infection of grape flowers: light and electron microscopical studies of infection sites. Phytopathology 94(8): 850-857.

Ziogas B.N., Markoglou A.N., Malandrakis A.A., 2003. Studies on the inherent resistance risk to fenhexamid in Botrytis cinerea. European Journal of Plant Pathology 109: 311-317. 